Elsevier required licence: (c) $<2018>$. This manuscript version is made available under the CC-BY-NC-ND 4.0 license http://creativecommons.org/licenses/bync-nd/4.0/ 


\section{Sustainability evaluation and implication of a large scale membrane bioreactor} plant

Zhuo CHEN ${ }^{\mathrm{a}, *}$, Dan WANG ${ }^{\mathrm{a}, b^{*}}$, Mingxing $\mathrm{SUN}^{\mathrm{c}}$, Huu Hao NGO ${ }^{\mathrm{d}}$, Wenshan GUO ${ }^{\mathrm{d}}$, Guangxue WU ${ }^{\mathrm{b}, \mathrm{e}}$, Wenjie JIA ${ }^{\mathrm{f}}$, Lei SHI ${ }^{\mathrm{a}}$, Qianyuan $\mathrm{WU}^{\mathrm{b}, \mathrm{e}}$, Fang GUO ${ }^{\mathrm{g}}$, Hong-Ying $\mathrm{HU}^{\mathrm{a}, \mathrm{e}, * *}$

${ }^{\text {a }}$ Environmental Simulation and Pollution Control State Key Joint Laboratory, State Environmental Protection Key Laboratory of Microorganism Application and Risk Control (SMARC), School of Environment, Tsinghua University, Beijing 100084, PR China

${ }^{\mathrm{b}}$ Key Laboratory of Microorganism Application and Risk Control of Shenzhen, Graduate School at Shenzhen, Tsinghua University, Shenzhen 518055, PR China

${ }^{\mathrm{c}}$ International Ecosystem Management Partnership, Institute of Geographic Sciences and Natural Resources Research, Chinese Academy of Sciences, Beijing 100101, PR China

${ }^{\mathrm{d}}$ School of Civil and Environmental Engineering, University of Technology Sydney, Broadway, NSW 2007, Australia

Shenzhen Environmental Science and New Energy Technology Engineering

Laboratory, Tsinghua-Berkeley Shenzhen Institute, Shenzhen 518055, PR China

${ }_{\mathrm{f}}^{\mathrm{f}}$ Research Institute for Environmental Innovation (Suzhou), Tsinghua University,

Suzhou 215163, PR China

${ }^{\mathrm{g}}$ Kunming Dianchi Water Treatment Co. Ltd., Kunming 650228, PR China 
*These authors contributed equally to this article and are joint first authors

**Corresponding author. Tel: +86 1062794005 ; Fax: +86 10 62797265. E-mail address: hyhu@tsinghua.edu.cn (H.-Y. Hu)

\section{Abstract}

Membrane bioreactor (MBR) technology is receiving increasing attention in wastewater treatment and reuse. This study presents an integral sustainability evaluation of a full scale MBR plant. The plant is capable of achieving prominent technical performance in terms of high compliance rate, low variation in effluent quality and high removal efficiency during long term operation. It is also more responsive to the new local standard with rigorous limits. However, electricity consumption is found to be the dominant process resulting in elevated life cycle environmental impacts and costs, accounting for $51.6 \%$ of the costs. As such, it is suggested to optimize energy use in MBR unit and implement sludge treatment and management. The prolonged membrane life span could also contribute largely to reduced life cycle environmental concerns and expenses. This study is of great theoretical significance and applicable value in guaranteeing the performance and sustainability of large scale MBR schemes.

Keywords: Membrane bioreactor (MBR); sustainability evaluation; energy use; sludge treatment; membrane life span 


\section{Introduction}

Given the rapid pace of population growth, urbanization, industrialization, social and economic growth, climate change and living standard enhancement, water scarcity and water contamination have become prominent around the globe (Jiménez-Cisneros, 2014; UNWWAP, 2015). Water related issues are closely linked to human health, food, agriculture, energy, industrial activity and social stability (Oh and Lee, 2018). It is estimated that global water demand will increase by over $50 \%$ by the year 2050 which inevitably challenges water security for human society and the environment (UNDESA, 2015). In this regard, turning wastewater into a resource is an essential part to promote efficient use and move towards a more circular economy approach (Makropoulos et al., 2018). Notably, reclaimed water is being widely practiced in many water-scarce regions as an alternative water resource not only for non-potable applications but also for indirect and direct potable water reuses (Herman et al., 2017).

As for existing water treatment and reuse technologies, membrane bioreactors (MBRs) have been widely applied in more than 200 countries over the last 20 years because of their apparent strengths including the reduced chemical use, superior effluent quality, operational flexibility and reliability, lower excess sludge production and small footprint (Huang and Lee, 2015; Barreto et al., 2017). It is estimated that by 2019 more than 5 million $\mathrm{m}^{3} / \mathrm{d}$ of wastewater will be treated by MBR plants worldwide and the global market value for MBR technology by that time is projected to reach 3 billion US dollars (Judd, 2016). Noticeably, the compound annual growth rate for MBRs during the 
period 2014-2019 is expected to be $17.4 \%$ in Asia-Pacific region, compared to $15 \%$, 9.6\% and $11.9 \%$ in globe, Europe and North America respectively (Krzeminski et al., 2017). It is predicted that China and Brazil will attain the fastest growth rates within the given forecast period (Abass et al., 2015). To be more specific, the number of large scale MBRs in China was about 200 by the end of 2017, with a capacity of over 4.5 million $\mathrm{m}^{3} / \mathrm{d}$ and an expected market value of 1.3 billion US dollars (Xiao et al., 2014; Hao et al., 2018; Li et al., 2019).

The above-mentioned figures further drive a boom in scientific research and industrial applications of full scale MBRs in a sustainable pathway. Particularly, barriers with respect to energy consumption, high capital and operational costs, membrane fouling, membrane life span and full scale operational experiences are highly concerned and are likely to restrain MBR market expansion (Ma et al., 2017; Bagheri and Mirbagheri, 2018). A large quantity of studies have already devoted to membrane fouling control through the design of new configurations (Yan et al., 2015), the addition of granular media such as activated carbon, zeolite, sludge-based adsorbent, plastic barriers and quorum quenching enzymes (Iorhemen et al., 2017; Nahm et al., 2017) or the modification of membrane material by nanomaterials (Meng et al., 2017).

Nowadays, multi-faceted challenges can no longer be solved by traditional limited scale and monotonous factor approaches. However, the sustainability assessment of MBRs in terms of technical, economic and environmental aspects is limited to few studies (Krzeminski et al., 2017). 
Memon et al. (2007) and Ortiz et al. (2007) analyzed environmental aspect of water reuse systems at small scales and concluded that MBRs provoked higher environmental impact than conventional activated sludge and natural treatment systems (e.g. the reed beds and green roof water recycling system) due to higher energy demands. Similarly, Hospido et al. (2012) evaluated the environmental profiles of different MBR configurations on a pilot scale and identified an inverse relation between the environmental impact and technological complexity. Likewise, Ioannou-Ttofa et al. (2016) examined the environmental footprint of an MBR pilot unit without consideration of its sludge treatment and disposal. It is found that energy consumption and membrane unit's material are main impact contributors. Besides, Molinos-Senante et al. (2012) integrated the environmental assessment tool with cost-benefit approach of several technologies in small WWTPs and addressed the advantages of MBRs in terms of high effluent quality production. Nevertheless, there is a continuous doubt that whether experiences based on small or pilot scale MBR studies could actually offer a reliable view since the limited scale could negatively influence the energy performance (Fenu et al., 2010; Krzeminski et al., 2017; Salgot and Folch, 2018).

In addition, Høibye et al. (2008) proposed the concept of holistic assessment of advanced treatment technologies considering technical, economic and environmental aspects. Likewise, Plakas et al. (2016) suggested a multi-criteria analysis of advanced treatment technologies from a perspective of economic, environmental and social concerns. Furthermore, Hao et al. (2018) and Akhoundi and Nazif (2018) established 
corresponding models to evaluate the sustainability of MBRs. However, their effectiveness and applicability to full scale MBR applications need further research. Presently, there is still a significant challenge to identify the benefits of large scale MBRs for sustainable water reuse under risk and uncertainty while addressing the technical, economic and environmental implications. Hence, this study aims to investigate experiences of full scale MBR via a case study and evaluate performances and advances based on integrative analyses that involve multiple dimensions and indexes concurrently. The results can be beneficial to real practices and expansion of MBRs and offer a better understanding of the interlinkages among water, energy, nutrient and material towards maximum use and recovery.

\section{Methods}

\subsection{Description of study area}

In China, in addition to water shortage and high quality reclaimed water demand, the growth of MBR technology is also largely driven by ever stringent water discharge regulation, water reuse standard as well as potentials for upgrading existing WWTPs (Abass et al., 2015). Notably, the anaerobic/anoxic/oxic (AAO) MBR and its derivate processes have become prevailing process compared to oxic MBR and anoxic/oxic

MBR for large scale municipal applications (Xiao et al., 2014). In AAO-MBR, the elimination of potential membrane foulants especially soluble extracellular polymeric substances in AAO process is regarded as beneficial to downstream MBR process (Krzeminski et al., 2017; Wang et al., 2017). Therefore, a large scale AAO-MBR plant 
with a capacity of $60,000 \mathrm{~m}^{3} / \mathrm{d}$ in Kunming city of China was selected as a case study. For comparison, another adjacent water reclamation plant (WRP) with ACTIFLO (i.e. coagulation and flocculation) processes $\left(210,000 \mathrm{~m}^{3} / \mathrm{d}\right)$ was analyzed as a reference (Fig. 1).

\subsection{Analytical methods}

In this study, three dimensions, namely technical, environmental and economic aspects are taken into account for integral sustainability evaluation (Plakas et al., 2016; Akhoundi and Nazif, 2018). Social indexes (e.g. public awareness, acceptance and local development) are excluded from consideration since relevant quantitative data is not available in the study while qualitative information is likely to introduce bias (Chen et al., 2014). The functional unit of the study was the production of $1 \mathrm{~m}^{3}$ of reclaimed water.

\subsubsection{Technical aspect}

Statistical analyses on wastewater influent and effluent quality parameters including biochemical oxygen demand (BOD), chemical oxygen demand (COD), suspended solids (SS), ammonia-nitrogen $\left(\mathrm{NH}_{3}-\mathrm{N}\right)$, total nitrogen $(\mathrm{TN})$ and total phosphorus (TP) were conducted by Microsoft Excel and the software package OriginPro 2017 version (developed by OriginLab Corporation, Northampton, USA). Afterwards, the technical performance of the plant was further evaluated by compliance rate, stability of effluent quality, removal efficiency and removal loading. The figures were plotted using the OriginPro 2017 version. The effluent compliance rate is shown in 
Eq. (1):

Compliancerate $=\frac{N_{s}}{N_{t}} \times 100 \%$

where, $N_{s}$ refers to the number of samples of which the discharged effluent quality meet the corresponding standard values; $N_{t}$ refers to the total number of samples.

The stability of effluent quality, removal efficiency and removal loading are described in Eqs. (2), (3) and (4) respectively:

Stability of effluent quality $=\frac{S D_{\text {eff }}}{\text { Mean }_{\text {eff }}} \times 100 \%$

Removal efficiency $=\frac{C_{i n}-C_{e f f}}{C_{i n}} \times 100 \%$

Removal loading $=C_{i n}-C_{e f f}$

where, $S D_{\text {eff }}$ is the standard deviation of effluent quality; Mean eff is the average value of effluent quality; $C_{i n}$ is the concentration of influent parameter; $C_{e f f}$ is the concentration of effluent parameter.

The Class $1 \mathrm{~A}$ water quality of Chinese national discharge standard of pollutants for municipal WWTPs (GB18918- 2002) has a minimum requirement of $\mathrm{BOD}_{5}<10 \mathrm{mg} / \mathrm{L}$, $\mathrm{COD}_{\mathrm{Cr}}<50 \mathrm{mg} / \mathrm{L}, \mathrm{SS}<10 \mathrm{mg} / \mathrm{L}, \mathrm{TN}<15 \mathrm{mg} / \mathrm{L}, \mathrm{TP}<0.5 \mathrm{mg} / \mathrm{L}$ and $\mathrm{NH}_{3}-\mathrm{N}<5 \mathrm{mg} / \mathrm{L}$. It is specified that effluent meeting Class $1 \mathrm{~A}$ level can be reused in a recreational or scenic environment that has less diluting capacity (Sun et al., 2016). Moreover, to further reduce pollutant loadings and improve local water environment, the government is planning to release a new local discharge standard of WWTPs. The forthcoming standard will stipulate more rigorous limits with $\mathrm{BOD}_{5}<6 \mathrm{mg} / \mathrm{L}, \mathrm{COD}_{\mathrm{Cr}}<30 \mathrm{mg} / \mathrm{L}$, 
$\mathrm{TN}<10 \mathrm{mg} / \mathrm{L}, \mathrm{TP}<0.3 \mathrm{mg} / \mathrm{L}$ and $\mathrm{NH}_{3}-\mathrm{N}<1.5 \mathrm{mg} / \mathrm{L}$.

\subsubsection{Environmental aspect}

Life cycle assessment (LCA) is conducted to assess the environmental aspects of two WRPs thoroughly. As depicted Fig. 1, the system boundaries include all wastewater treatment process units. All the energy and mass input and output flows, all the chemicals used at different treatment units and sludge treatment are considered. The construction and demolition phase of the life cycle of WRPs were excluded from the system boundary because of limited environmental impacts and lack of data (Qin et al., 2018; Sun et al., 2018). The detailed modeling and calculation processes are performed by GaBi CML2001 LCA software. Fifteen midpoint categories are included in the methodology: aquatic acidification, aquatic ecotoxicity, aquatic eutrophication, carcinogens, global warming potential, ionizing radiation, land occupation, mineral extraction, non-carcinogens, non-renewable energy, ozone layer depletion, photochemical oxidation, respiratory effects, terrestrial acidification/ nitrification, and terrestrial ecotoxicity. For ease of comparison, the midpoint categories per unit of emission were further normalized by the per capita world impact for the year 2000 (Sleeswijk et al., 2008). The life cycle inventory data are shown in Table 1. All the inputs, outputs and emissions are presented based on the functional unit of $1 \mathrm{~m}^{3}$ of treated water.

\subsubsection{Economic aspect}

For economic assessment, life cycle cost (LCC) is performed where the capital and 
operation and maintenance costs of the WRPs are taken into account (Table 1) and calculated as expense per functional unit. According to the actual design planning, the life span of plant A and B are measured as 23 and 25 years respectively. Capital costs include the costs associated with civil works, equipment and land acquisition, while operation and maintenance costs include the costs related to energy consumption, chemicals consumption, MBR membrane material consumption (i.e. polyvinylidene fluoride, PVDF) and pollution discharge (i.e. water emission in terms of $\mathrm{COD}, \mathrm{SS}, \mathrm{NH}_{3}-$ $\mathrm{N}, \mathrm{NO}_{3}-\mathrm{N}$ and $\mathrm{TP}$ and sludge disposal). All these costs data are sourced from field investigation.

\section{Results and discussion}

\subsection{Technical performance}

Fig. 2 presents the concentrations of six crucial water quality parameters in influent and effluent of both WRPs. Notably, the sources of wastewater influent are mainly from municipal sewage streams, as well as a possible mixture of industrial wastewater, stormwater and surface water. Hence, compared with pure industrial wastewaters, the influent quality of two plants is relatively stable and has low contamination of organic matters and nutrients. Since the two plants are located in adjacent areas, their influent quality possesses similar contamination levels. The concentrations of all water quality parameters in effluent of both plants were decreased largely. However, since different treatment processes were applied in these two plants, their technical performances with respond to effluent quality are further evaluated. Additional details of the parameter 
values are given in Appendix A.

Presently, the discharged effluent of both plants follows the Class 1A level of national standard and is subsequently supplied for scenic environmental uses in Dianchi Lake. As a consequence, overall effluent limit compliance rates should be maintained at acceptable levels. As can be seen from Fig. 3, the MBR plant performs well with all water quality parameters achieve $100 \%$ compliance with the national guideline limits. Comparatively, lower compliance rates were observed in plant A (ACTIFLO) where only $\mathrm{BOD}_{5}$ and $\mathrm{COD}_{\mathrm{Cr}}$ concentrations reached at $100 \%$ compliance rates.

Based on the new local guideline limits, corresponding compliance rates of both plants are calculated. As shown in Fig. 3, the effluent quality of MBR plant will still achieve a satisfactory effect with an average compliance rate of $97 \%$ in all parameters except for TN. In comparison, when improving the discharge limit, effluent compliance rates of water quality parameters in plant A (ACTIFLO) will decrease sharply, suggesting additional treatment need to be conducted. Nevertheless, under this scenario, both plants should pay attention to extra nitrogen removal.

Besides, the operation and management of WRPs is likely to be affected by multiple factors, such as shock loadings of influent quality (e.g. toxic and harmful wastewater intrusion), sudden failure of one treatment unit and microbial reactivation after disinfection. A key capability of the WRP is to ensure the stability of effluent quality despite of complex and varying situations. According to Fig. 3, MBR plant produces a more stable effluent quality due to less variations in concentrations of water 
quality parameters. As for removal efficiency, the MBR plant exhibits better performances than plant $\mathrm{A}$ in terms of $\mathrm{BOD}_{5}, \mathrm{COD}_{\mathrm{Cr}}, \mathrm{SS}, \mathrm{TN}, \mathrm{TP}$ and $\mathrm{NH}_{4}-\mathrm{N}$ removal. Particularly, the removal efficiencies of all water quality parameters in MBR plant are above $95 \%$ expect for TN. However, the removal efficiency of TN is only $58.3 \%$ and $69.9 \%$ in plant A and B respectively. Similar phenomenon was detected by Zhang et al. (2016) which shows that nearly $90 \%$ of WWTPs demonstrated poor removal efficiency for nitrogen and phosphorus, especially the TN. Furthermore, removal loadings per unit of treated effluent of plant A is slightly higher than that of MBR plant.

\subsection{Environmental performance}

The LCA midpoint results and dominant contributing processes are summarized in Table 2. In plant A, dominant processes that contributed to the environmental impact are electricity, sludge landfill, direct emissions and PAC production. Comparatively, for the MBR plant, dominant processes in environmental performance are electricity, sludge landfill, PVDF consumption and direct emissions. The results are in accordance with other reported findings by Ioannou-Ttofa et al. (2016). Particularly, sludge landfill is a major factor contributing significantly to most impact categories. This indicates that the current treatment method of sludge via direct landfill can be environmental unfriendly.

Alternative treatment approaches of sludge such as anaerobic digestion and advanced oxidation can be considered (Pang et al., 2018). Besides, to maximize energy recovery and move towards energy positive wastewater treatment, novel sludge treatment technologies such as biosolids gasification, free ammonia and free nitrous acid (e.g. 
$\mathrm{HNO}_{2}$ ) are also being increasingly explored and analyzed (Wang et al., 2016; Gikas, 2017; Wang, 2017).

For both of the WRPs, electricity was also an important contributor to the overall environmental burden. Noticeably, for the MBR plant, since the membranes need to be replaced every four years, environmental impacts related to MBR membrane material consumption (i.e. PVDF) should be addressed. When the membrane life span can be possibly extended, such as through effective membrane fouling control or employment of new material, membrane material associated effects can be reduced to a large extent. For instance, when the membrane life span can be extended to 8 years, the life cycle environmental impact of the main PVDF affected category (i.e. carcinogens) can be reduced to 0.0195 compared with 0.0274 in current circumstances (Table 2). Further, Ioannou-Ttofa et al. (2016) claimed that the adoption of a more environmentally friendly membrane material (i.e. ethylene propylene diene monomer) is likely to reduce life cycle costs and introduce less impact on the environment.

Moreover, the normalized midpoint results are illustrated in Fig. 4. It is observed that categories including aquatic acidification, aquatic ecotoxicity, respiratory effects, non-carcinogens, terrestrial acidification/nitrification, carcinogens and global warming potential are major components of the overall environmental impact. By contrast, other LCIA categories play relatively minor roles in assessing environmental performance of the WRPs and can thusly be neglected. Further investigation indicates that sludge landfill and electricity are the most significant sides that are likely to result in elevated 
aquatic ecotoxicity. To be more specific, the contributions of different treatment processes and categories in the MBR plant to the ultimate environmental impact are further explored (Fig. 5). It is apparent that the MBR unit alone is likely to introduce environmental burdens in terms of ozone layer depletion, mineral extraction and ionizing radiation. Apart from sludge landfill and electricity consumption, the production, use and demolishment of PVDF in the MBR plant, also contribute largely to the categories of carcinogens and non-carcinogens.

Besides, sensitivity analysis was also conducted to identify the main influences that can affect the LCA results. Table 3 presents the results of a $10 \%$ variations in main contributing factors. It can be found that for the MBR plant, a $10 \%$ variation in electricity consumption can lead to a change of respiratory effect, aquatic acidification, global warming, and terrestrial acidification/nitrification potentials of 7.89\%, 6.16\%, $5.60 \%$ and $4.17 \%$ respectively. Likewise, varying the amount of sludge for landfill disposal can also greatly influence major environmental impact categories. The results indicate that if electricity consumption of the MBR plant can be cut down to a certain degree or electricity can be produced largely by renewable energies (e.g. solar and hydroelectricity) rather than fossil fuel consumptions, overall environmental impact of the MBR plant can be reduced considerably (Ortiz et al., 2007; Ioannou-Ttofa et al., 2016) and can be even lower than plants equipped with conventional treatment technologies. Similarly, more effort should be paid for sludge treatment. It is noteworthy that for aquatic and terrestrial acidification concerns, attentions should be 
paid to $\mathrm{TN}$ and $\mathrm{NH}_{3}-\mathrm{N}$ concentrations of the effluents as well. Additionally, as shown in

Table 4, uncertainty analysis was performed to determine the degree of confidence in LCA results.

\subsection{Economic performance}

According to Fig. 6, the LCC results suggest that the expense per functional unit of the MBR plant is slightly higher than that of Plant A. The largest increase of expense is attributed to the energy consumption of MBR, which occupies about $51.6 \%$ of the total LCC expenses. Similar results were demonstrated in Abass et al. (2015). Presently, the electricity consumption of the MBR plant $\left(60,000 \mathrm{~m}^{3} / \mathrm{d}\right)$ is estimated to be $0.47-0.56$ $\mathrm{kWh} / \mathrm{m}^{3}$. Given the economy of the scale, the energy consumption of a larger scale MBR plant is expected to be lower than the current plant. For instance, the electricity consumption of two MBR plants in China (i.e. 150,000 and $200,000 \mathrm{~m}^{3} / \mathrm{d}$ ) is reported as 0.33 and $0.31-0.46 \mathrm{kWh} / \mathrm{m}^{3}$ respectively (Li et al., 2019). Nevertheless, the costs of MBR plant in the aspects of pollution discharge, chemical inputs and capital investment are almost the same as Plant A. Hence, the MBR plant would be more competitive if the energy consumption can be reduced further (Cashman et al., 2018).

\subsection{Overall consideration and evaluation}

The technical performance of the MBR plant exhibit distinct strengths over traditional treatment technologies with respect to compliance rate, stability of effluent quality and removal efficiency and the facility is more adaptive to ever stringent standard limits. This is vital for the long-term operation of wastewater treatment and 
reuse projects (Xiao et al., 2014). However, from the life cycle perspective, superior technical performance of the existing large scale MBR plant is also accompanied by considerable environmental burdens and high costs. The relatively high electricity consumption and direct landfill of sludge become significant obstacles to the continuous application and expansion of MBR technologies. Their environmental impacts can be possibly reduced by enhanced aeration efficiency, use of high-flux membrane material, change of energy production models and adoption of sound sludge treatment and energy recovery facilities.

While the strengths and weaknesses of MBR schemes need to be further weighed, it is worth noting that the values of different dimensions in technical, environmental and economic aspects are normally manifested in varied forms (e.g. quantitative calculations and qualitative estimations) with different unit scales (e.g. monetary, volumetric and concentration unit). To attain a gross result of the comprehensive evaluation, normalization, weighting and aggregation processes of multiple dimensions can be further considered and performed (Chen et al., 2014; Wang et al., 2018). The commonly used aggregation methods include the data envelopment method (Lorenzo-Toja et al., 2015; Castellet and Molinos-Senante, 2016), analytic hierarchy process (MolinosSenante et al., 2014; Kalbar et al., 2013), fuzzy comprehensive evaluation method (Tan et al., 2014), etc. However, although the data envelopment method does not require weight distribution, there are requirements on the number of evaluation objects. Besides, both analytic hierarchy process and fuzzy comprehensive evaluation methods 
require weight assignment. These two methods are highly subjective since a series of subjective factors are involved (e.g. personal perception, natural environment, economic condition, local policies, local and specific assumptions, etc.) (Ouyang et al., 2015). Consequently, due to limited local data on the relative importance or relevance of multiple factors, this study only conducts an initial single-factor evaluation in multiple aspects. The overall comprehensive evaluation can be performed in the future when more information on priorities of multiple factors and managerial preferences is available.

\section{Conclusions}

This study conducted a sustainability evaluation of a full scale MBR plant in terms of technical, environmental and economic aspects. Statistical analyses on six crucial water quality parameters indicate that MBR technology could achieve satisfactory technical performance and is adaptive to increasingly stringent standard limits. Aquatic ecotoxicity is identified as the major category contributing to overall environmental impact. Continuous understanding on energy use pattern, sludge treatment and membrane material can facilitate the implementation of sound management strategies. Aggregation of multiple dimensions to achieve a general score can be further performed when additional field information are available.

\section{Acknowledgements}

This work was supported by the National Key Research and Development Program of China (2017YFF0206702 \& 2016YFE0118800). 


\section{Appendix A. Supplementary data}

Supplementary data associated with this article can be found, in the online version.

\section{References}

1. Abass, O.K., Wu, X., Guo, Y.Z., Zhang, K.S., 2015. Membrane bioreactor in China: A critical review. Int. J. Membrane Sci. Technol. 2, 29-47.

2. Akhoundi, A., Nazif, S., 2018. Sustainability assessment of wastewater reuse alternatives using the evidential reasoning approach. J. Clean. Prod. 195, 1350-1376.

3. Bagheri, M., Mirbagheri, S.A., 2018. Critical review of fouling mitigation strategies in membrane bioreactors treating water and wastewater. Bioresour. Technol. 258, 318-334.

4. Barreto, C.M., Garcia, H.A., Hooijmans, C.M., Herrera, A., Barreto, D., 2017. Assessing the performance of an MBR operated at high biomass concentrations. Int. Biodeter. Biodegr. 119, 528-537.

5. Cashman, S., Ma, X., Mosley, J., Garland, J., Crone, B., Xue, X., 2018. Energy and greenhouse gas life cycle assessment and cost analysis of aerobic and anaerobic membrane bioreactor systems: Influence of scale, population density, climate, and methane recovery. Bioresour. Technol. 254, 56-66.

6. Castellet, L., Molinos-Senante, M., 2016. Efficiency assessment of wastewater treatment plants: A data envelopment analysis approach integrating technical, economic, and environmental issues. J. Environ. Manage. 167, 160-166.

7. Chen, Z., Ngo, H.H., Guo, W.S., Lim, R., Wang, X.C., O’ Halloran, K., Listowski, A., Corby, N., Miechel, C., 2014. A comprehensive framework for the assessment of new end 
uses in recycled water schemes. Sci. Total Environ. 470-471, 44-52.

8. Fenu, A., Roels, J., Wambecq, T., De Gussem, K., Thoeye, C., De Gueldre, G., Van De Steene, B., 2010. Energy audit of a full scale MBR system. Desalination 262, 121-128.

9. Gikas, P., 2017. Towards energy positive wastewater treatment plants. J. Environ. Manage. 203, 621-629.

10. Hao, X.D., Li, J., van Loosdrecht, M.C.M., Li, T.Y., 2018. A sustainability-based evaluation of membrane bioreactors over conventional activated sludge processes. J. Environ. Chem. Eng. 6, 2597-2605.

11. Herman, J.G., Scruggs, C.E., Thomson, B.M., 2017. The costs of direct and indirect potable water reuse in a medium-sized arid inland community. J. Water Process Eng. 19, 239-247.

12. Høibye, L., Clauson-Kaas, J., Wenzei, H., Larsen, H.F., Jacobsen, B.N., Dalgaard, O., 2008. Sustainability assessment of advanced wastewater treatment technologies. Water Sci. Technol. 58, 963-968.

13. Hospido, A., Sanchez, I., Rodriguez-Garcia, G., Iglesias, A., Buntner, D., Reif, R., Moreira, M.T., Feijoo, G., 2012. Are all membrane reactors equal from an environmental point of view? Desalination 285, 263-270.

14. Huang, L., Lee, D.J., 2015. Membrane bioreactor: A mini review on recent R\&D works. Bioresour. Technol. 194, 383-388.

15. Ioannou-Ttofa, L., Foteinis, S., Chatzisymeon, E., Fatta-Kassinos, D., 2016. The environmental footprint of a membrane bioreactor treatment process through life cycle analysis. Sci. Total Environ. 568, 306-318. 
16. Iorhemen, O.T., Hamza, R.A., Tay, J.H., 2017. Membrane fouling control in membrane bioreactors (MBRs) using granular materials. Bioresour. Technol. 240, 9-24.

17. Judd, S.J., 2016. The status of industrial and municipal effluent treatment with membrane bioreactor technology. Chem. Eng. J. 305, 37-45.

18. Kalbar, P.P., Karmakar, S., Asolekar, S.R., 2012. Selection of an appropriate wastewater treatment technology: A scenario-based multiple-attribute decision-making approach. J. Environ. Manage. 113, 158-169.

19. Krzeminski, P., Leverette, L., Malamis, S., Katsou, E., 2017. Membrane bioreactors - A review on recent developments in energy reduction, fouling control, novel configurations, LCA and market prospects. J. Membrane Sci. 527, 207-227.

20. Jiménez-Cisneros, B., 2014. Water reuse and recycling, in: Ahuja S. (Ed.), Comprehensive Water Quality and Purification. Elsevier, UK, Volume 3, 296-323.

21. Li, P., Liu, L., Wu, J., Cheng, R., Shi, L., Zheng, X., Zhang, Z., 2019. Identify driving forces of MBR applications in China. Sci. Total Environ. 647, 627-638.

22. Lorenzo-Toja, Y., Vazquez-Rowe, I., Chenel, S., Marin-Navarro, D., Moreira, M.T., Feijoo, G., 2015. Eco-efficiency analysis of Spanish WWTPs using the LCA+ DEA method. Water Res. 68, 651-666.

23. Ma, J., Song, D., Wang, P.P., Wen, W.G., 2017. Membrane bioreactor application in water treatment, in: Drioli E., Giorno L. (Eds.), Comprehensive Membrane Science and Engineering ( $2^{\text {nd }}$ Ed.). Elsevier, UK, Volume 4, 104-117.

24. Makropoulos, C., Rozos, E., Tsoukalas, I., Plevri, A., Karakatsanis, G., Karagiannidis, L., 
Makri, E., Lioumis, C., Noutsopoulos, C., Mamais, D., Rippis, C., Lytras, E., 2018. Sewermining: A water reuse option supporting circular economy, public service provision and entrepreneurship. J. Environ. Manage. 216, 285-298.

25. Memon, F.A., Zheng, Z., Bulter, D., Shirley-Smith, C., Liu, S., Makropoulos, C., Avery, L. 2007. Life cycle impact assessment of greywater recycling technologies for new developments. Environ. Monit. Assess. 129, 27-35.

26. Meng, F., Zhang, S., Oh, Y., Zhou, Z., Shin, H., Chae, S., 2017. Fouling in membrane bioreactors: An updated review. Water Res. 114, 151-180.

27. Molinos-Senante, M., Gómez, T., Garrido-Baserba, M., Caballero, R., Sala-Garrido, R., 2014. Assessing the sustainability of small wastewater treatment systems: A composite indicator approach. Sci. Total Environ. 497, 607-617.

28. Molinos-Senante, M., Garrido-Baserba, M., Reif, R., Hernández-Sancho, F., Poch, M., 2012. Assessment of wastewater treatment plant design for small communities:

Environmental and economic aspects. Sci. Total Environ. 427-428, 11-18.

29. Nahm, C.H., Choi, D.C., Kwon, H., Lee, S., Lee, S.H., Lee, K., Choo, K.H., Lee, J.K., Lee, C.H., Park, P.K., 2017. Application of quorum quenching bacteria entrapping sheets to enhance biofouling control in a membrane bioreactor with a hollow fiber module. J. Membrane Sci. 526, 264-271.

30. Oh, H.S., Lee, C.H., 2018. Origin and evolution of quorum quenching technology for biofouling control in MBRs for wastewater treatment. J. Membrane Sci. 554, 331-345.

31. Ortiz, M., Raluy, R. G., Serra, L., 2007. Life cycle assessment of water treatment 
technologies: wastewater and water-reuse in a small town. Desalination 204, 121-131.

32. Ouyang, X.G., Guo, F., Shan, D., Yu, H.Y., Wang, J., 2015. Development of the integrated fuzzy analytical hierarchy process with multidimensional scaling in selection of natural wastewater treatment alternatives. Ecol. Eng. 74, 438-447.

33. Pang, L., Ge, L.M., Yang, P.J., He, H., Zhang, H.Z., 2018. Degradation of organophosphate esters in sewage sludge: Effects of aerobic/ anaerobic treatments and bacterial community compositions. Bioresour. Technol. 255, 16-21.

34. Plakas K.V., Georgiadis A.A., Karabelas A.J., 2016. Sustainability assessment of tertiary wastewater treatment technologies: A multi-criteria analysis. Water Sci. Technol. 73, 15321540.

35. Qin, Z., Sun, M., Luo, X., Zhang, H., Xie, J., Chen, H., Yang, L., Shi, L., 2018. Life-cycle assessment of tobacco stalk utilization. Bioresour. Technol. 265, 119-127.

36. Salgot, M., Folch, M., 2018. Wastewater treatment and water reuse. Curr. Opin. Environ. Sci. Health 2, 64-74.

37. Sleeswijk, A.W., van Oers, L.F., Guinee, J.B., Struijs, J., Huijbregts, M.A., 2008. Normalisation in product life cycle assessment: an LCA of the global and European economic systems in the year 2000. Sci. Total Environ. 390, 227-240.

38. Snip, L. 2010. Quantifying the greenhouse gases emissions of wastewater treatment plants. Msc thesis. Department of Agrotechnology and Food Science. Wageningen University. Departement de genie civil. Universite Laval. Available at http://edepot.wur.nl/138115 (Accessed on 15th Jan, 2018). 
39. Sun, M., Wang, Y., Shi, L., 2018. Environmental performance of straw-based pulp making: a life cycle perspective. Sci. Total Environ. 616-617, 753-762.

40. Sun, Y., Chen, Z., Wu, G.X., Wu, Q.Y., Zhang, F., Niu, Z., Hu, H.Y., 2016. Characteristics of water quality of municipal wastewater treatment plants in China: Implications for resources utilization and management. J. Clean. Prod. 131, 1-9.

41. Tan, R.R., Aviso, K.B., Huelgas, A.P., Promentilla, M.A.B., 2014. Fuzzy AHP approach to selection problems in process engineering involving quantitative and qualitative aspects. Process. Saf. Environ. 92(5), 467-475.

42. UNDESA (United Nations Department of Economic and Social Affairs), 2015. World Urbanization Prospects: The 2014 Revision, Highlights. (ST/ESA/SER.A/352). New York, United Nations (UN). Available at http://esa.un.org/unpd/wup/ (Accessed on 13th Jan, 2016).

43. UNWWAP (United Nations World Water Assessment Programme), 2015. The United Nations World Water Development Report 2015: Water for a Sustainable World. Paris, UNESCO.

44. Wang, Q., Hao, X., Yuan, Z., 2016. Towards energy positive wastewater treatment by sludge treatment using free nitrous acid. Chemosphere 144, 1869-1873.

45. Wang, Q., 2017. A roadmap for achieving energy-positive sewage treatment based on sludge treatment using free ammonia. ACS Sustain. Chem. Eng. 5, 9630-9633.

46. Wang, D., Wu, Y., Guo, F., Li, Z., Wu, G., 2017. Comprehensive assessment of system performance in a full-scale wastewater treatment plant with the 3AMBR/ozonation process. 
The IWA Conference on Sustainable Wastewater Treatment and Resource Recovery:

Research, Planning, Design and Operation. November 7-10, 2017, Chongqing, China.

47. Wang, D., Guo, F., Wu, Y.H., Li, Z.P., Wu, G.X., 2018. Technical, economic and environmental assessment of coagulation/filtration tertiary treatment processes in full-scale wastewater treatment plants. J. Clean. Prod. 170, 1185-1194.

48. Xiao, K., Xu, Y., Liang, S., Lei, T., Sun, J. Y., Wen, X. H., Zhang, H. X., Chen, C. S., Huang, X., 2014. Engineering application of membrane bioreactor for wastewater treatment in China: current state and future prospect. Front. Environ. Sci. Eng. 8, 805-819.

49. Yan, X., Xiao, K., Liang, S., Lei, T., Liang, P., Xue, T., Ku, K., Guan, J., Huang, X., 2015. Hydraulic optimization of membrane bioreactor via baffle modification using computational fluid dynamics. Bioresour. Technol. 175, 633-637.

50. Zhang, Q.H., Yang, W.N., Ngo, H.H., Guo, W.S., Jin, P.K., Dzakpasu, M., Yang, S.J., Wang, Q., Wang, X.C., Ao, D., 2016. Current status of urban wastewater treatment plants in China. Environ. Int. 92, 11-22.

\section{Figures captions}

Fig. 1 Generic flow chart and system boundary of two WRPs

Fig. 2 Influent and effluent water quality of plant A (ACTIFLO) and plant B (MBR) during 2014

Fig. 3 Technical performances of two WRPs during 2014

Fig. 4 Normalized midpoint scores for the full LCA of two WRPs

Fig. 5 Contributions of different treatment processes and categories to midpoint scores 
in LCA of plant B (MBR)

Fig. 6 Life cycle cost of two WRPs

\section{List of Tables}

Table 1. The LCIA inventory for life cycle assessment of two WRPs

Table 2. The life cycle environmental impacts of two WRPs and the main contributors of different impact categories

Table 3. The sensitivity of main contributors in LCA of two WRPs

Table 4. The uncertainty analysis of the LCA midpoint results of two WRPs
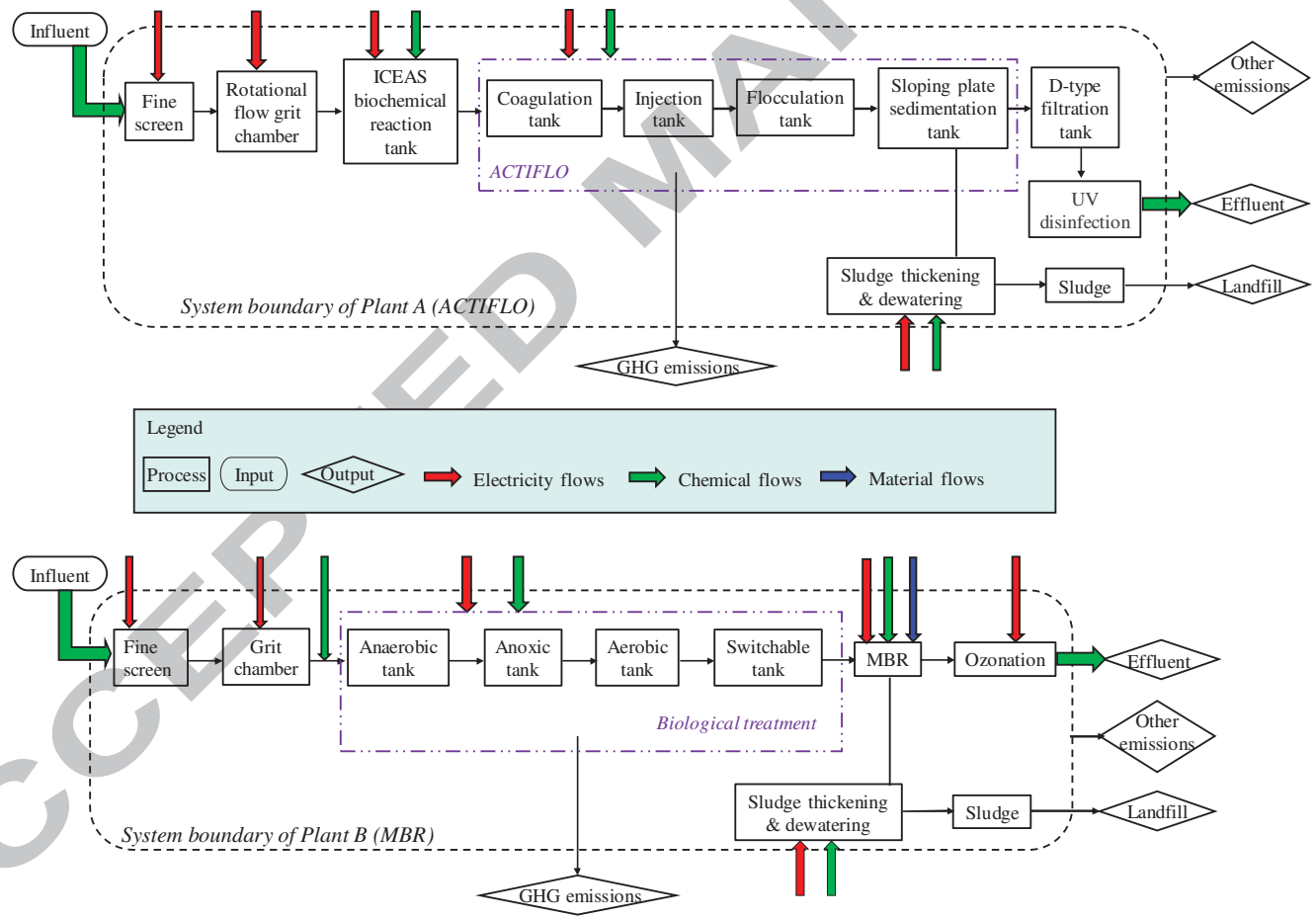

Fig. 1 Generic flow chart and system boundary of two WRPs 


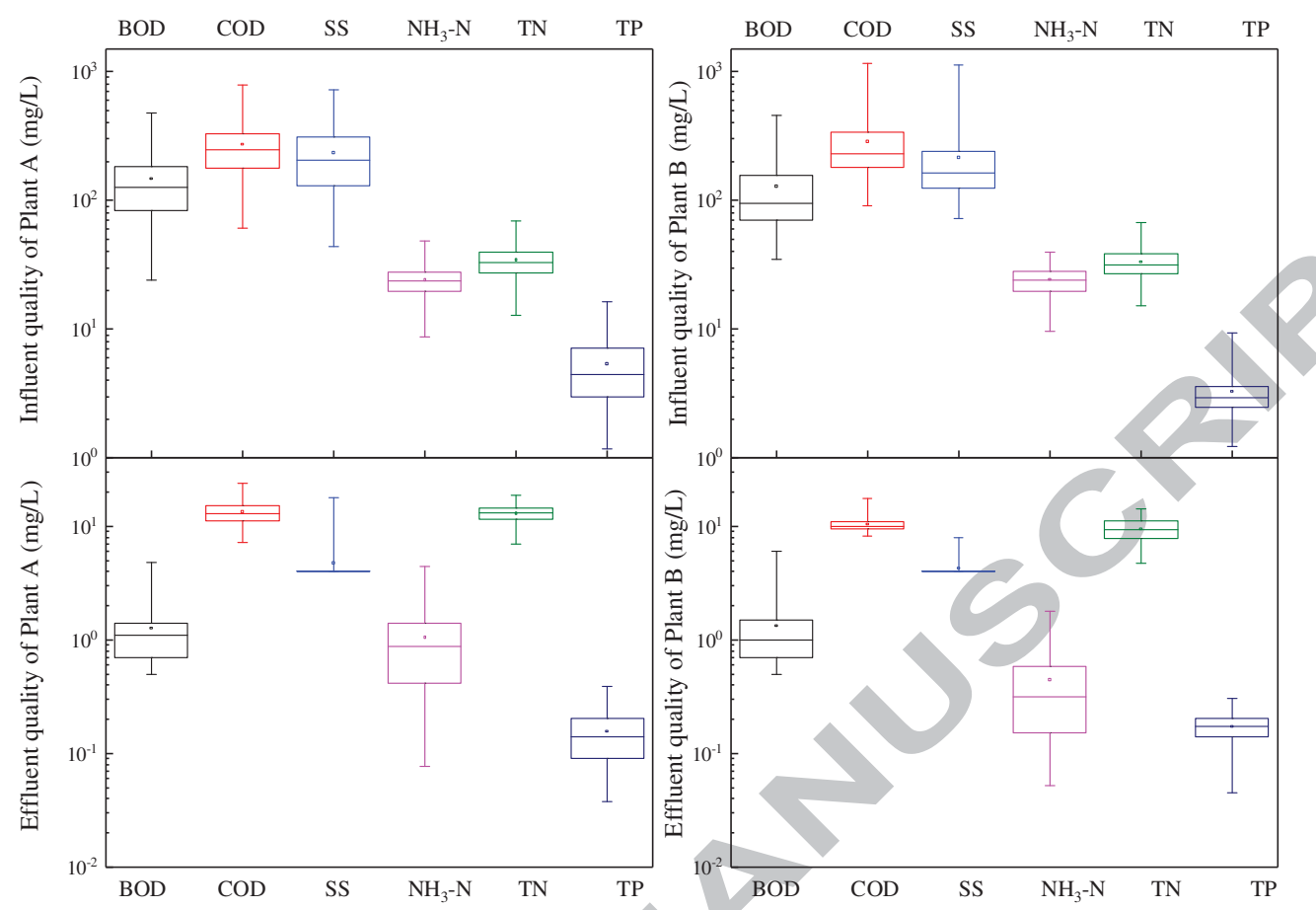

Fig. 2 Influent and effluent water quality of plant A (ACTIFLO) and plant B (MBR) during 2014

Notes: For each water quality parameter, the bottom and top of the box represent the 25 th and 75th percentile respectively, the band and the hollow square represent the 50th percentile (median) and the mean value. 

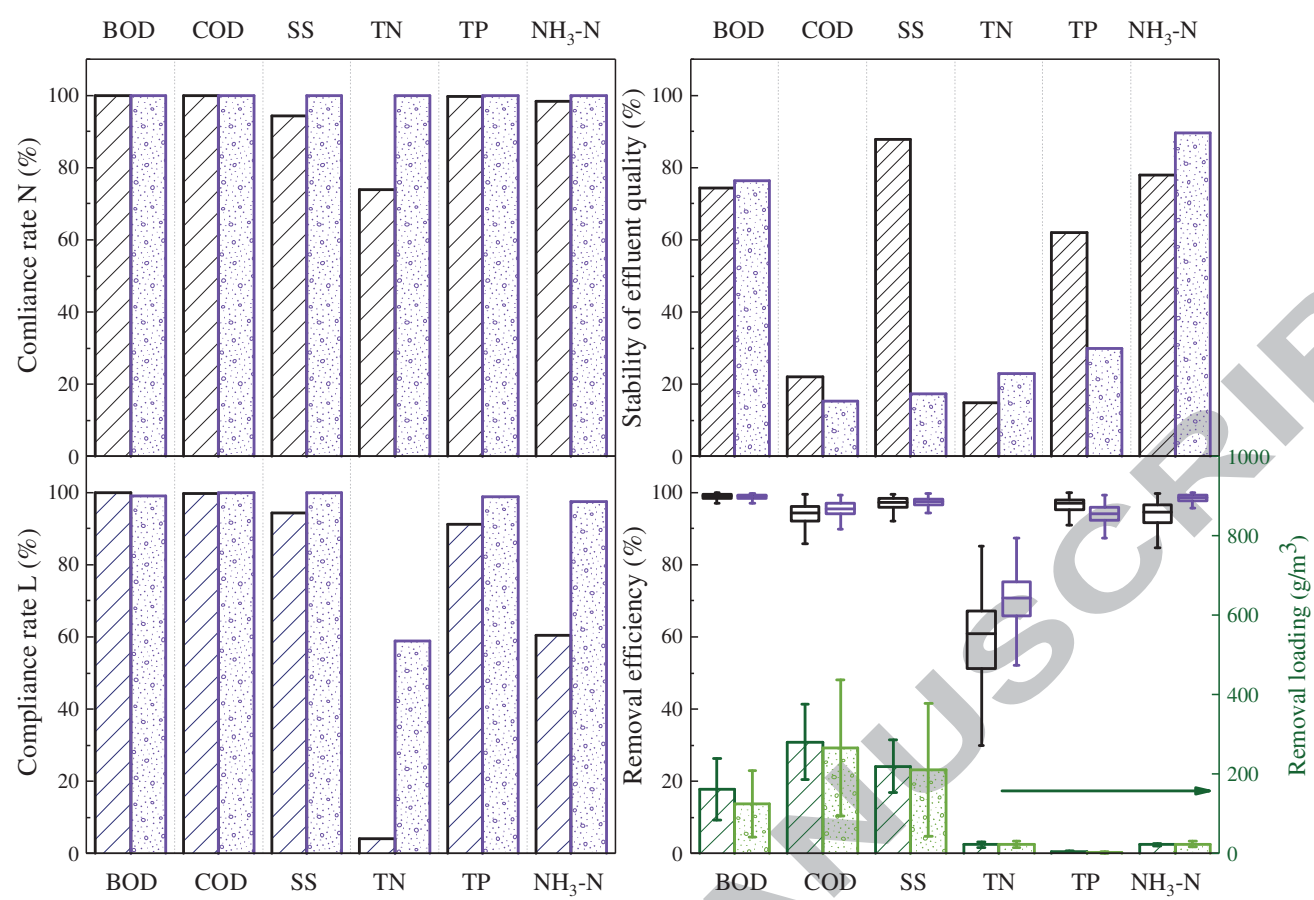

$\square$ Plant A (ACTIFLO) $\square$ Plant B (MBR)

Fig. 3 Technical performances of two WRPs during 2014

Notes: $\mathrm{N}$ refers to compliance rates that correspond to Class $1 \mathrm{~A}$ water quality of Chinese national discharge standard of pollutants for municipal WWTPs (GB18918-2002). L refers to compliance rates that correspond to forthcoming local standard in Kunming. 


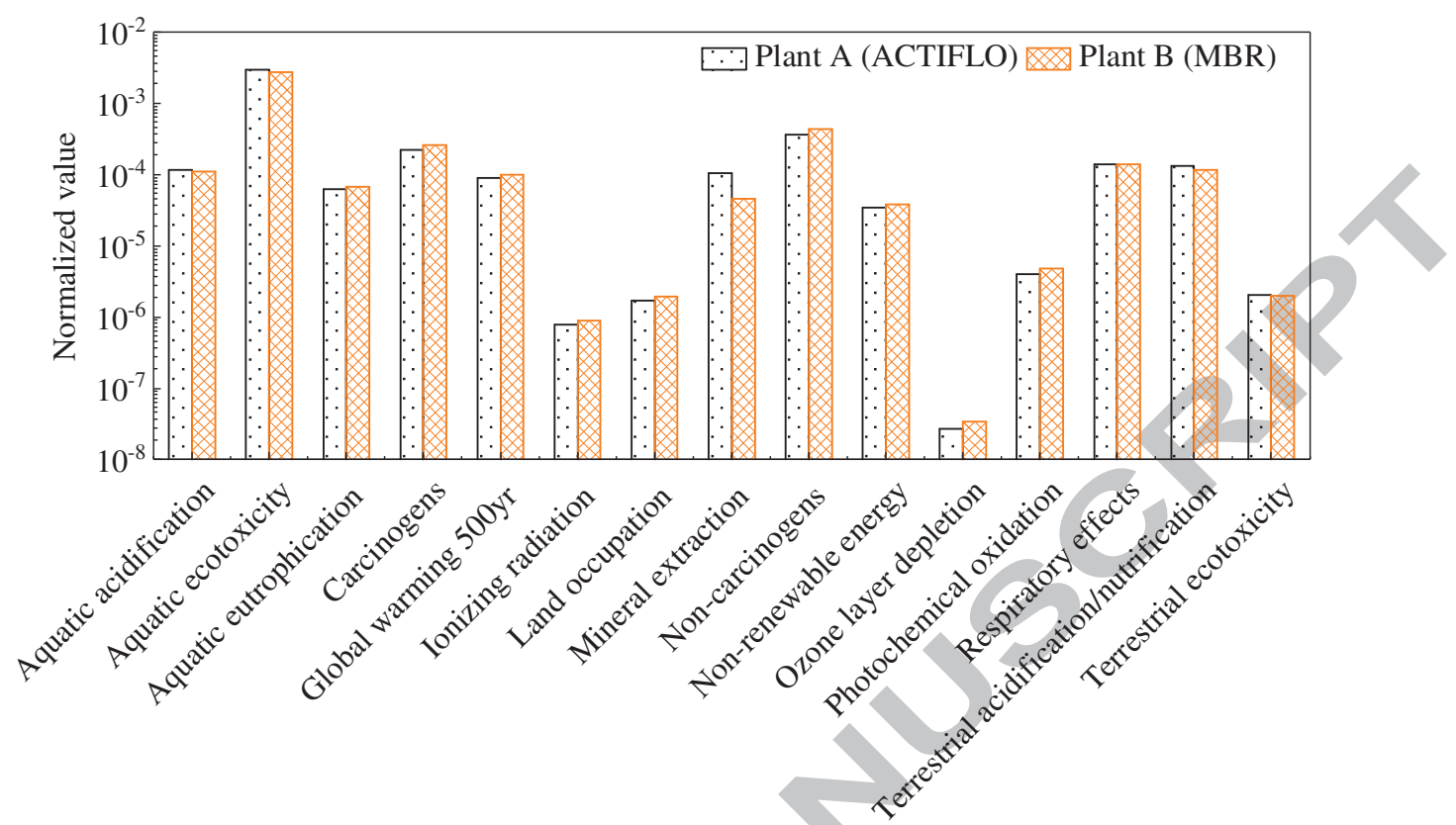

Environmental impact category

Fig. 4 Normalized midpoint scores for the full LCA of two WRPs 

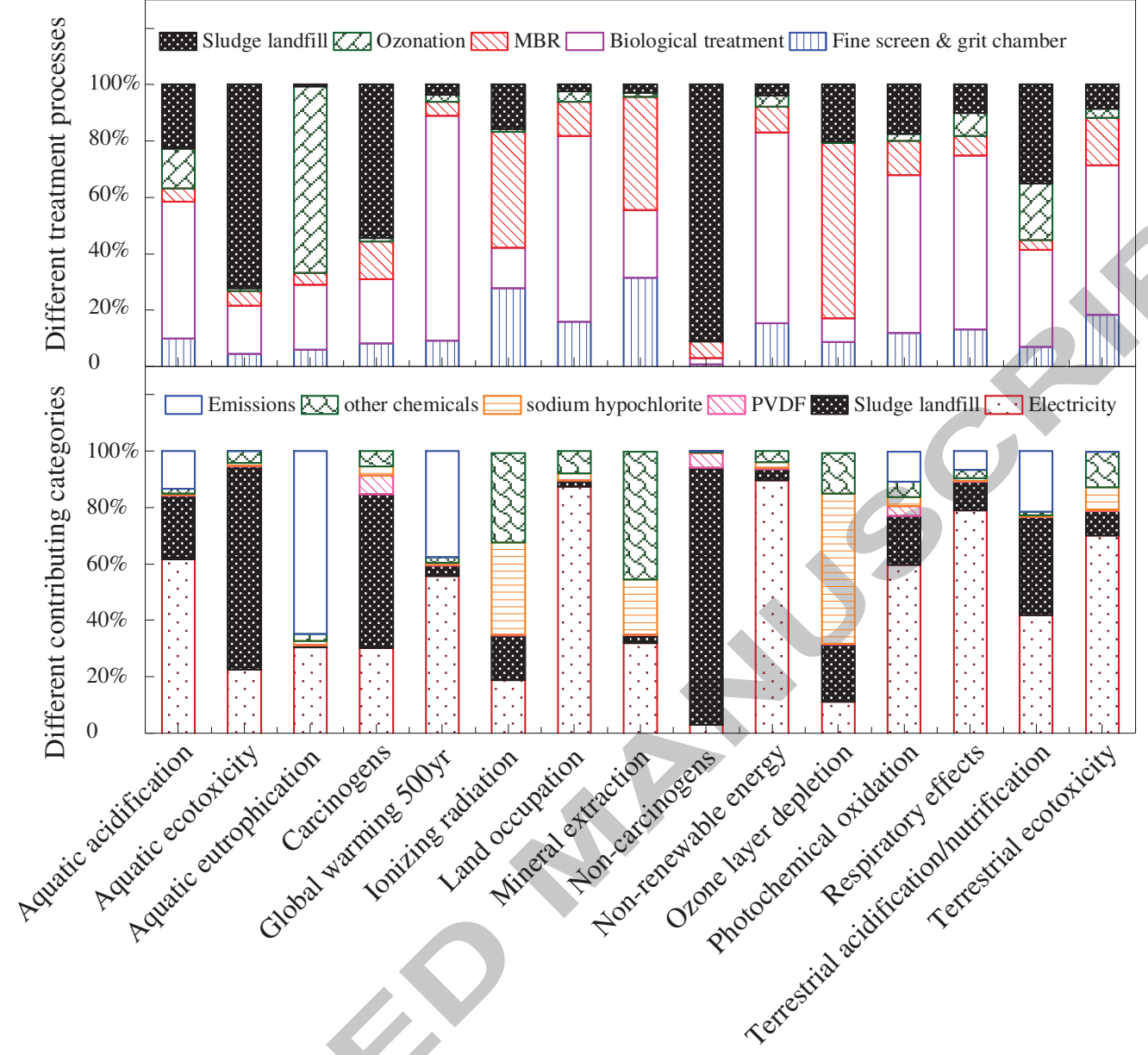

Environmental impact category

Fig. 5 Contributions of different treatment processes and categories to midpoint scores in LCA of plant B (MBR) 


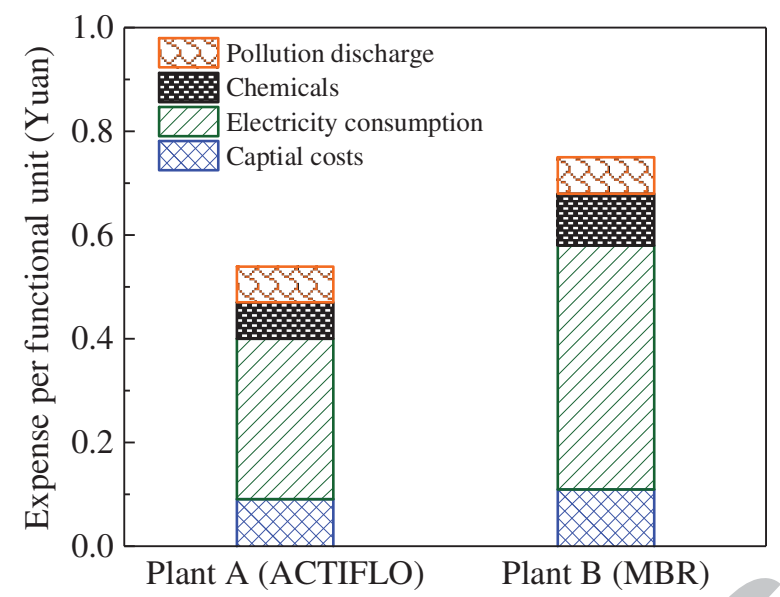

Fig. 6 Life cycle cost of two WRPs 
Table 1. The LCIA inventory for life cycle assessment of two WRPs

\begin{tabular}{|c|c|c|c|c|c|}
\hline Material inputs & Unit & $\begin{array}{l}\text { Plant A } \\
\text { (ACTIFLO) }\end{array}$ & $\begin{array}{l}\text { Plant B } \\
\text { (MBR) }\end{array}$ & Source & $\begin{array}{l}\text { Price } \\
\text { Yuan/kg }\end{array}$ \\
\hline Electricity & kwh & 0.305 & 0.469 & Field investigation & 1 \\
\hline Tap water & $\mathrm{g}$ & 196.78 & 99.41 & Field investigation & 0.00485 \\
\hline $\begin{array}{l}\text { PAC (poly aluminium } \\
\text { chloride) }\end{array}$ & $\mathrm{g}$ & 68.95 & 6.47 & Field investigation & 0.67 \\
\hline Quartz sand (small size) & $\mathrm{g}$ & 0.564 & & Field investigation & 2.066 \\
\hline PAM (polyacrylamide) & $\mathrm{g}$ & 0.6 & & Field investigation & 21 \\
\hline $\begin{array}{l}\text { PFS (polymeric ferric } \\
\text { sulfate) }\end{array}$ & $\mathrm{g}$ & 5.58 & & Field investigation & 1.26 \\
\hline $\mathrm{FeSO}_{4}$ & g & & 18.98 & Field investigation & 0.39 \\
\hline $\mathrm{NaOH}$ & g & & 0.09 & Field investigation & 4.5 \\
\hline $\mathrm{NaClO}$ & $\mathrm{g}$ & & 8.15 & Field investigation & 1.2 \\
\hline Citric acid & $\mathrm{g}$ & & 0.49 & Field investigation & 9 \\
\hline PVDF (membrane material) & $\mathrm{g}$ & & 0.53 & Field investigation & 141.51 \\
\hline \multicolumn{6}{|l|}{ Gas emissions } \\
\hline $\mathrm{CO}_{2}$ & g & 346.41 & 362.97 & $\begin{array}{l}\text { Calculated from } \\
\text { Stoichiometry }\end{array}$ & \\
\hline $\mathrm{N}_{2} \mathrm{O}$ & $\mathrm{g}$ & 0.1329 & 0.134 & $\begin{array}{l}\text { Calculated from } \\
\text { Stoichiometry }\end{array}$ & \\
\hline $\mathrm{CH}_{4}$ & $\mathrm{~g}$ & . & 1.058 & $\begin{array}{l}\text { Calculated from } \\
\text { Stoichiometry }\end{array}$ & \\
\hline \multicolumn{6}{|l|}{ Water emissions",\# } \\
\hline COD & g & $\begin{array}{l}13.34 \\
{[9,19.3]}\end{array}$ & $\begin{array}{l}10.48 \\
{[9,13.1]}\end{array}$ & Field investigation & 1.4 \\
\hline SS & $\mathrm{g}$ & $4.76[4,8]$ & $4.27[4,6]$ & Field investigation & 0.35 \\
\hline $\mathrm{NH}_{3}-\mathrm{N}$ & $\mathrm{g}$ & $\begin{array}{l}1.05 \\
{[0.14,2.8]}\end{array}$ & $\begin{array}{l}0.45 \\
{[0.082,1.28]}\end{array}$ & Field investigation & 1.75 \\
\hline $\mathrm{NO}_{3}-\mathrm{N}$ & $\mathrm{g}$ & $\begin{array}{l}11.88 \\
{[8.55,13.9]}\end{array}$ & $\begin{array}{l}8.99 \\
{[5.85,11.42]}\end{array}$ & Field investigation & \\
\hline Total P & $\mathrm{g}$ & $\begin{array}{l}0.16 \\
{[0.056,0.33]}\end{array}$ & $\begin{array}{l}0.17 \\
{[0.085,0.262]}\end{array}$ & Field investigation & 5.6 \\
\hline \multicolumn{6}{|l|}{ Solid waste ${ }^{*}$} \\
\hline $\begin{array}{l}\text { Sludge ( } 80 \% \text { moisture } \\
\text { content) }\end{array}$ & $\mathrm{g}$ & $\begin{array}{l}465.83 \\
{[239.8,754]}\end{array}$ & $\begin{array}{l}532.22 \\
{[297.1,794]}\end{array}$ & Field investigation & 0.09 \\
\hline
\end{tabular}

Notes: *The numbers in the bracket are the ends of $95 \%$ confidence interval of water and solid wastes generation. \#The price of the pollutants in the water emissions is taken from The Law of China Environmental Protection Tax. Gas emissions calculated from stoichiometry refer to equations described by Snip (2010) and Wang et al. (2017). 
Table 2. The life cycle environmental impacts of two WRPs and the main contributors of different impact categories

\begin{tabular}{|c|c|c|c|c|c|}
\hline \multirow{2}{*}{$\begin{array}{l}\text { Environmental } \\
\text { impact category }\end{array}$} & \multirow[t]{2}{*}{ Unit } & \multicolumn{2}{|c|}{ Plant A (ACTIFLO) } & \multicolumn{2}{|c|}{ Plant B (MBR) } \\
\hline & & Value & $\begin{array}{l}\text { Dominating } \\
\text { contributing processes }\end{array}$ & Value & $\begin{array}{l}\text { Dominating } \\
\text { contributing processes }\end{array}$ \\
\hline $\begin{array}{l}\text { Aquatic } \\
\text { acidification }\end{array}$ & $\begin{array}{l}\mathrm{kg} \mathrm{SO}_{2} \text {-Eq. } \\
\text { to air }\end{array}$ & $\begin{array}{l}2.06 \mathrm{E} \\
-02\end{array}$ & $\begin{array}{l}\text { Direct emissions } \\
(71.43 \%)+\text { Electricity } \\
(15.11 \%)\end{array}$ & $\begin{array}{l}7.60 \mathrm{E} \\
-03\end{array}$ & $\begin{array}{l}\text { Electricity }(62.81 \%) \\
\text { +Sludge landfill } \\
(32.71 \%)\end{array}$ \\
\hline $\begin{array}{l}\text { Aquatic } \\
\text { ecotoxicity }\end{array}$ & $\begin{array}{l}\mathrm{kg} \text { TEG- } \\
\text { Eq. to } \\
\text { water }\end{array}$ & $\begin{array}{l}4.53 \mathrm{E} \\
+03\end{array}$ & $\begin{array}{l}\text { Sludge landfill } \\
(61.55 \%)+\mathrm{PAC} \\
\text { production }(25.46 \%)\end{array}$ & $\begin{array}{l}5.19 \mathrm{E} \\
+03\end{array}$ & $\begin{array}{l}\text { Sludge landfill } \\
(76.63 \%)+\text { Electricity } \\
(16.75 \%)\end{array}$ \\
\hline $\begin{array}{l}\text { Aquatic } \\
\text { eutrophication }\end{array}$ & $\begin{array}{l}\mathrm{kg} \mathrm{PO}_{4} \text {-Eq. } \\
\text { to water }\end{array}$ & $\begin{array}{l}7.48 \mathrm{E} \\
-04\end{array}$ & $\begin{array}{l}\text { Direct emissions } \\
(65.44 \%)+\text { Electricity } \\
(22.26 \%)\end{array}$ & & Electricity $(83.08 \%)$ \\
\hline Carcino & $\begin{array}{l}\mathrm{kg} \mathrm{C}_{2} \mathrm{H}_{3} \mathrm{Cl}- \\
\text { Eq. to air }\end{array}$ & $\begin{array}{l}1.12 \mathrm{E} \\
-02\end{array}$ & $\begin{array}{l}\text { Sludge landfill } \\
(60.30 \%)+\text { Electricity } \\
(22.03 \%)\end{array}$ & $\begin{array}{l}2.74 \mathrm{E} \\
-02\end{array}$ & $\begin{array}{l}\text { PVDF (47.32\%) } \\
\text { +Sludge landfill } \\
(35.11 \%)\end{array}$ \\
\hline Global warming & $\mathrm{kg} \mathrm{CO}_{2^{-}}$ & $9.07 \mathrm{E}$ & Electricity $(41.25 \%)$ & $8.27 \mathrm{E}$ & Electricity $(69.51 \%)$ \\
\hline $500 \mathrm{yr}$ & Eq. to air & -01 & $\begin{array}{l}\text { +Direct emissions } \\
(38.25 \%)\end{array}$ & -01 & $\begin{array}{l}\text { +Direct emissions } \\
(15.92 \%)\end{array}$ \\
\hline Ionizing radiation & $\mathrm{BqC}$ & & $\begin{array}{l}\text { PAC production } \\
(56.33 \%)+\text { Sludge } \\
\text { landfill }(18.26 \%)\end{array}$ & $\begin{array}{l}5.34 \mathrm{E} \\
-01\end{array}$ & $\begin{array}{l}\text { Sodium hypochlorite } \\
(29.07 \%)+\text { Iron sulfate } \\
(21.56 \%)+\text { Sludge } \\
\text { landfill }(20.92 \%)\end{array}$ \\
\hline $\mathrm{La}$ & $\mathrm{m}^{2} * \mathrm{yr}-\mathrm{Eq}$ & $\begin{array}{l}5.88 \mathrm{E} \\
-03\end{array}$ & $\begin{array}{l}\text { Electricity }(67.68 \%) \\
+\mathrm{PAC} \text { production } \\
(28.48 \%)\end{array}$ & $\begin{array}{l}7.11 \mathrm{E} \\
-03\end{array}$ & Electricity $(86.01 \%)$ \\
\hline $\begin{array}{l}\text { Mineral } \\
\text { extraction }\end{array}$ & MJ surplus & $\begin{array}{l}3.06 \mathrm{E} \\
-02\end{array}$ & $\begin{array}{l}\text { PAC production } \\
(82.54 \%)\end{array}$ & $\begin{array}{l}1.41 \mathrm{E} \\
-02\end{array}$ & $\begin{array}{l}\text { Electricity }(32.14 \%) \\
\text { +Iron sulfate }(25.06 \%) \\
\text { +Sodium hypochlorite } \\
(18.57 \%)\end{array}$ \\
\hline Non-carcinogens & $\begin{array}{l}\mathrm{kg} \mathrm{C}_{2} \mathrm{H}_{3} \mathrm{Cl}- \\
\text { Eq. to air }\end{array}$ & $\begin{array}{l}7.45 \mathrm{E} \\
-02\end{array}$ & $\begin{array}{l}\text { Sludge landfill } \\
(95.86 \%)\end{array}$ & $\begin{array}{l}1.70 \mathrm{E} \\
-01\end{array}$ & $\begin{array}{l}\text { Sludge landfill } \\
(60.13 \%)+\text { PVDF } \\
(38.15 \%)\end{array}$ \\
\hline $\begin{array}{l}\text { Non-renewable } \\
\text { energy }\end{array}$ & MJ & $\begin{array}{l}5.29 \mathrm{E} \\
+00\end{array}$ & $\begin{array}{l}\text { Electricity }(67.00 \%) \\
+ \text { PAC production } \\
(27.37 \%)\end{array}$ & $\begin{array}{l}6.76 \mathrm{E} \\
+00\end{array}$ & Electricity $(80.49 \%)$ \\
\hline
\end{tabular}




\begin{tabular}{|c|c|c|c|c|c|}
\hline $\begin{array}{l}\text { Ozone layer } \\
\text { depletion }\end{array}$ & $\begin{array}{l}\mathrm{kg} \mathrm{CFC}- \\
\text { 11-Eq. to } \\
\text { air }\end{array}$ & $\begin{array}{l}5.75 \mathrm{E} \\
-09\end{array}$ & $\begin{array}{l}\text { PAC production } \\
(55.88 \%)+\text { Sludge } \\
\text { landfill }(25.66 \%)\end{array}$ & $\begin{array}{l}8.08 \mathrm{E} \\
-09\end{array}$ & $\begin{array}{l}\text { Sodium hypochlorite } \\
(45.85 \%)+\text { Electricity } \\
(26.06 \%)\end{array}$ \\
\hline $\begin{array}{l}\text { Photochemical } \\
\text { oxidation }\end{array}$ & $\begin{array}{l}\mathrm{kg} \mathrm{C}_{2} \mathrm{H}_{4-} \\
\text { Eq. to air }\end{array}$ & $\begin{array}{l}5.19 \mathrm{E} \\
-05\end{array}$ & $\begin{array}{l}\text { Electricity }(46.28 \%) \\
\text { +PAC production } \\
(29.09 \%)\end{array}$ & $\begin{array}{l}9.01 \mathrm{E} \\
-05\end{array}$ & $\begin{array}{l}\text { Electricity }(40.92 \%) \\
+\operatorname{PVDF}(36.39 \%)\end{array}$ \\
\hline $\begin{array}{l}\text { Respiratory } \\
\text { effects }\end{array}$ & $\begin{array}{l}\mathrm{kg} \text { PM2.5- } \\
\text { Eq. to air }\end{array}$ & $\begin{array}{l}3.54 \mathrm{E} \\
-03\end{array}$ & $\begin{array}{l}\text { Direct emissions } \\
(71.43 \%)+\text { Electricity } \\
(15.11 \%)\end{array}$ & $\begin{array}{l}1.32 \mathrm{E} \\
-03\end{array}$ & Electri \\
\hline $\begin{array}{l}\text { Terrestrial } \\
\text { acidification/nutri } \\
\text { fication }\end{array}$ & $\begin{array}{l}\mathrm{kg} \mathrm{SO}_{2} \text {-Eq. } \\
\text { to air }\end{array}$ & $\begin{array}{l}1.43 \mathrm{E} \\
-01\end{array}$ & $\begin{array}{l}\text { Direct emissions } \\
(80.92 \%)\end{array}$ & $\begin{array}{l}3.65 \mathrm{E} \\
-02\end{array}$ & $\begin{array}{l}\text { Sludge landfill } \\
(52.35 \%)+\text { Electricity } \\
(44.02 \%)\end{array}$ \\
\hline $\begin{array}{l}\text { Terrestrial } \\
\text { ecotoxicity }\end{array}$ & $\begin{array}{l}\text { kg TEG- } \\
\text { Eq. to soil }\end{array}$ & $\begin{array}{l}2.52 \mathrm{E} \\
+00\end{array}$ & $\begin{array}{l}\text { Electricity }(45.12 \%) \\
+ \text { PAC production } \\
(41.24 \%)\end{array}$ & $2.67 \mathrm{E}$ & $\begin{array}{l}\text { Electricity }(65.47 \%) \\
\text { +Sludge landfill } \\
(11.39 \%)\end{array}$ \\
\hline
\end{tabular}




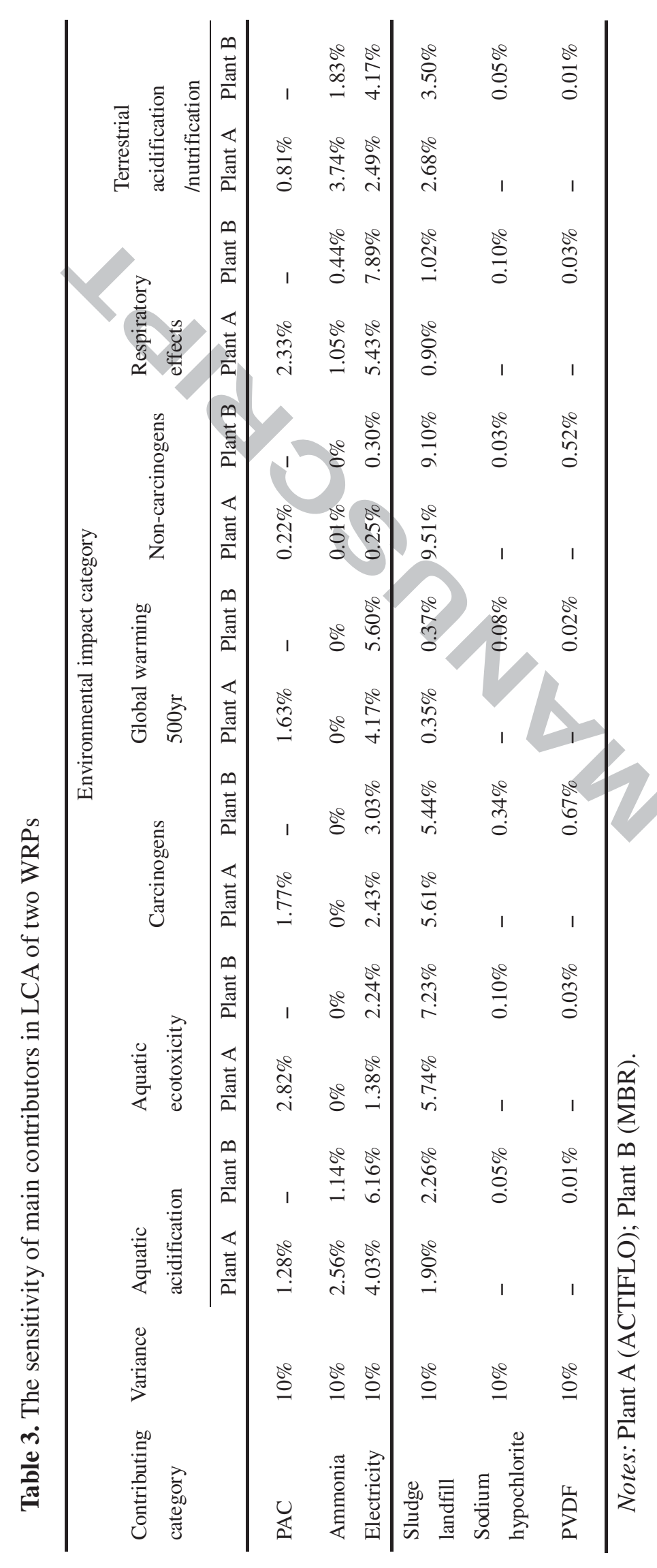


Table 4. The uncertainty analysis of the LCA midpoint results of two WRPs

\begin{tabular}{|c|c|c|c|c|c|}
\hline \multirow{2}{*}{$\begin{array}{l}\text { Environmental impact } \\
\text { category }\end{array}$} & \multirow[b]{2}{*}{ Unit } & \multicolumn{2}{|c|}{ Plant A (ACTIFLO) } & \multicolumn{2}{|c|}{ Plant B (MBR) } \\
\hline & & $\begin{array}{l}\text { Mean } \\
\text { value }\end{array}$ & $95 \%$ interval* & Mean value & $95 \%$ interval $*$ \\
\hline Aquatic acidification & $\begin{array}{l}\mathrm{kg} \mathrm{SO}_{2} \text {-Eq. to } \\
\text { air }\end{array}$ & 8.83E-03 & $\begin{array}{l}6.30 \mathrm{E}-03, \\
1.14 \mathrm{E}-02]\end{array}$ & $1.04 \mathrm{E}-02$ & $\begin{array}{l}7.75 \mathrm{E}-03 \\
1.31 \mathrm{E}-02]\end{array}$ \\
\hline Aquatic ecotoxicity & $\begin{array}{l}\text { kg TEG-Eq. to } \\
\text { water }\end{array}$ & $4.33 \mathrm{E}+03$ & $\begin{array}{l}{[3.24 \mathrm{E}+03} \\
5.42 \mathrm{E}+03]\end{array}$ & $7.21 \mathrm{E}+03$ & $\begin{array}{l}{[3.27 \mathrm{E}+03,} \\
1.12 \mathrm{E}+04]\end{array}$ \\
\hline Carcinogens & $\begin{array}{l}\mathrm{kg} \mathrm{C}_{2} \mathrm{H}_{3} \mathrm{Cl}-\mathrm{Eq} \text {. } \\
\text { to air }\end{array}$ & $1.07 \mathrm{E}-02$ & $\begin{array}{l}{[8.07 \mathrm{E}-03,} \\
1.33 \mathrm{E}-02]\end{array}$ & $2.04 \mathrm{E}-\mathrm{C}$ & $\begin{array}{l}{[1.09 \mathrm{E}-02,} \\
2.99 \mathrm{E}-02]\end{array}$ \\
\hline Global warming 500yr & $\begin{array}{l}\mathrm{kg} \mathrm{CO}_{2} \text {-Eq. to } \\
\text { air }\end{array}$ & $9.10 \mathrm{E}-01$ & $\begin{array}{l}{[8.95 \mathrm{E}-01,} \\
9.25 \mathrm{E}-01]\end{array}$ & $1.04 \mathrm{E}+00$ & $\begin{array}{l}{[9.87 \mathrm{E}-01} \\
1.09 \mathrm{E}+00]\end{array}$ \\
\hline Non-carcinogens & $\begin{array}{l}\mathrm{kg} \mathrm{C}_{2} \mathrm{H}_{3} \mathrm{Cl}-\mathrm{Eq} \text {. } \\
\text { to air }\end{array}$ & $6.94 \mathrm{E}-02$ & $\begin{array}{l}{[4.15 \mathrm{E}-02,} \\
9.73 \mathrm{E}-02]\end{array}$ & & $\begin{array}{l}{[6.40 \mathrm{E}-02} \\
2.66 \mathrm{E}-01]\end{array}$ \\
\hline Respiratory effects & $\begin{array}{l}\mathrm{kg} \text { PM2.5-Eq. } \\
\text { to air }\end{array}$ & $1.29 \mathrm{E}-03$ & $\begin{array}{l}{[1.12 \mathrm{E}-03} \\
1.46 \mathrm{E}-03]\end{array}$ & $1.45 \mathrm{E}-03$ & $\begin{array}{l}{[1.25 \mathrm{E}-03} \\
1.65 \mathrm{E}-03]\end{array}$ \\
\hline $\begin{array}{l}\text { Terrestrial } \\
\text { acidification/nutrification }\end{array}$ & $\begin{array}{l}\mathrm{kg} \mathrm{SO}_{2} \text {-Eq. to } \\
\text { air }\end{array}$ & $5.09 \mathrm{E}-02$ & $\begin{array}{l}{[3.09 \mathrm{E}-02,} \\
7.09 \mathrm{E}-02]\end{array}$ & $5.99 \mathrm{E}-02$ & $\begin{array}{l}{[3.94 \mathrm{E}-02} \\
8.04 \mathrm{E}-02]\end{array}$ \\
\hline
\end{tabular}

Note: *The numbers in the bracket are the ends of $95 \%$ confidence interval of the uncertainty analysis.

\section{Highlights}

- Sustainability evaluation is vital for MBR technology application and expansion

- Technical performance of a full scale MBR plant is analysed and discussed

- Major contributors to life cycle environmental impact and cost are identified

- Management strategies are proposed for further improvement of MBR sustainability

- Aggregation of multiple dimensions and additional data collection is recommended 